\title{
Minute Silurian oncocerid nautiloids with unusual colour patterns
}

Štěpán Manda and Vojtěch Turek

Acta Palaeontologica Polonica 54 (3), 2009: 503-512 doi: http://dx.doi.org/10.4202/app.2008.0062

A minute Silurian oncocerid Cyrtoceras pollux, from the Prague Basin is assigned here to the genus Pomerantsoceras. The only so far known species of this genus comes from the Upper Ordovician (Hirnantian) of Estonia. Pomerantsoceras thus represents, except for un-revised poorly understood taxa, the single known oncocerid genus surviving the end-Ordovician extinction events. Cyrtoceras pollux is unusual among the Silurian nautiloids because of its small shell. Colour pattern characterised by a few longitudinal bands on the entire circumference of the shell is here reported in oncocerids. Longicone and only slightly curved small shells as in Pomerantsoceras are unusual among nautiloids and resemble straight shells of orthocerids and pseudorthocerids, in which the colour pattern consists of straight colour bands. Consequently the shell shape as well as the colour pattern should be regarded as adaptive convergence with orthocerids and pseudorthocerids. It supports the hypothesis that colour pattern functioned as camouflage and its evolution was under adaptive control. In addition, several types of the shellmalformations including anomalous growth of septa, shell wall and pits on an internal mould are described.

Key words: Cephalopoda, Nautiloidea, taxonomy, colour pattern, shell size, shell malformation, Silurian.

Štěpán Manda [tepan.manda@geology.cz], Odbor regionální geologie sedimentárních formací, Česká geologická služba, PO Box 85, Praha 011, 118 21, Česká republika; Vojtěch Turek [vojtech turek@nm.cz], Národní muzeum, Oddělení paleontologie, Václavské náměstí 68, 11579 Praha 1, Česká republika.

This is an open-access article distributed under the terms of the Creative Commons Attribution License (for details please see creativecommons.org), which permits unrestricted use, distribution, and reproduction in any medium, provided the original author and source are credited. 
Fof Full text $(420.6 \mathrm{kB})$ 